\title{
DEVELOPMENT OF A GLASS POLYMER COMPOSITE SEWER PIPE FROM WASTE GLASS
}

\author{
PROGRESS REPORT N0. 7 \\ JANUARY - MARCH 1978
}

PROCESS SCIENCES DIVISION

DEPARTMENT OF ENERGY AND ENVIRONMENT

BROOKHAVEN NATIONAL LABORATORY ASSOCIATED UNIVERSITIES, INC.

UNDER CONTRACT NO. EY-76-C-02-0016 WITH THE

UNITED STATES DEPARTMENT OF ENERGY 


\section{DISCLAIMER}

This report was prepared as an account of work sponsored by an agency of the United States Government. Neither the United States Government nor any agency Thereof, nor any of their employees, makes any warranty, express or implied, or assumes any legal liability or responsibility for the accuracy, completeness, or usefulness of any information, apparatus, product, or process disclosed, or represents that its use would not infringe privately owned rights. Reference herein to any specific commercial product, process, or service by trade name, trademark, manufacturer, or otherwise does not necessarily constitute or imply its endorsement, recommendation, or favoring by the United States Government or any agency thereof. The views and opinions of authors expressed herein do not necessarily state or reflect those of the United States Government or any agency thereof. 


\section{DISCLAIMER}

Portions of this document may be illegible in electronic image products. Images are produced from the best available original document. 


\title{
DEVELOPMENT OF A GLASS POLYMER COMPOSITE SEWER PIPE FROM WASTE GLASS
}

\author{
PROGRESS REPORT N0. 7 \\ JANUARY - MARCH 1978
}

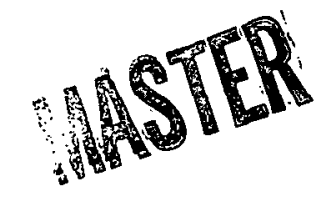

Contributors:
L.E. Kukacka
J. Fontana
R. Rayfiel
G. Arnold

B. Galen

WORK PERFORMED FOR THE DIVISION OF INDUSTRIAL ENERGY CONSERVATION

UNITED STATES DEPARTMENT OF ENERGY

WASHINGTON, D.C. 20545

M. STEINBERG, Head

L.E. KUKACKA - Project Leader

PROCESS SCIENCES DIVISION

DEPARTMENT OF ENERGY AND ENVIRONMENT

BROOKHAVEN NATIONAL LABORATORY

UPTON, NEW YORK 11973 


\section{N O T I C E}

This report was prepared as an account of work sponsored by the United States Government. Neither the United States nor the United States Department of Energy (DOE), nor any of their employees, nor any of their contractnrs, subcontractors, or their einployees, makes any warranty, express or implied, or assumes any legal liability or responsibility for the accuracy, completeness or usefulness of any information, apparatus, product or process disclosed, or represents that its use would not infringe privately owned rights.

Printed in the United States of America Available from

National Technical Information Service

U.S. Department of Commerce

5285 Port Royal Road

Springfield, VA 22161

Price: Printed Copy $\$ 4.00$; Microfiche $\$ 3.00$.

May 1978 


\begin{abstract}
Large quantities of energy can be conserved by recycling municipal solid waste. Reductions in the costs associated with waste disposal such as by landfilling can also be accrued. While uses for recycled ferrous and non-ferrous metals are apparent, uses for the glass fraction which constitutes $\sim 10 \%$ of municipal solid waste, have not been developed. As a result, a program to develop methods for incorporating waste glass into composites which can be used for construction materials was started in July 1976. Since that time the properties of as-produced glass polymer composite (GPC) sewer pipe have been measured, durability tests started and field testing of full-scale specimens initiated. Based upon the as-produced properties, calculations have been made to determine the energy requirements and costs. Work accomplished during the period January 1 - March 31, 1978 is described in the current report.
\end{abstract}




\section{Summary}

Tesţs have been started to determine the 1ong-term durability of glass polymer composite (GPC) sewer pipe in water at $65^{\circ} \mathrm{C}$ and $5 \% \mathrm{H}_{2} \mathrm{SO}_{4}$. For comparative purposes, sections of vitrified clay and asbestos cement pipe are also being tested.

Experiments to optimize the GPC mix formulation are continuing. Based upon these studies, reductions in polymer concentration from 12.2 $w t \%$ to $9 \mathrm{wt} \%$ may be possible. Considerable economic and energy conservation benefits will be accrued from this reduction. Compared with earlier estimates, at an assumed value for glass of $\$ 10 /$ ton, the cost of GPC pipe will be reduced by $\sim 12.4 \%$ from $9.7 \mathrm{c} / 1 \mathrm{~b}$ to $8.5 \mathrm{c} / 1 \mathrm{~b}$. The energy requirements to produce GPC pipe are estimated to be 16 to $40 \% 1$ ess than that for vitrified clay pipe. 


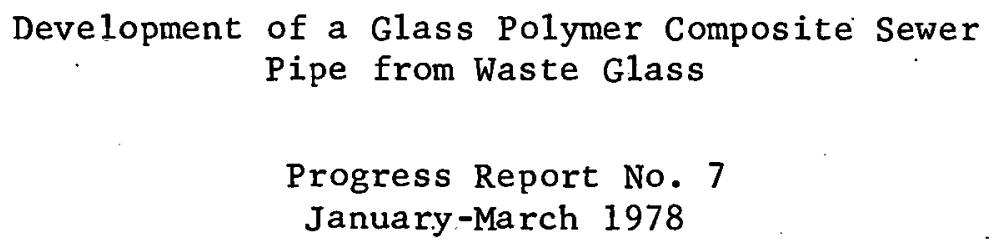

\section{Introduction}

The utilization of solid urban waste could result in many benefits. In addition to the production of substantial quantities of energy and the recovery of valuable materials, the costs associated with landfilling wastes would be lowered considerably. At the present time uses for recycled ferrous and non-ferrous metals are apparent. Efficient uses: for recycled glass which constitutes $\sim 10 \mathrm{wt} \%$ of urban waste in the US, need to be developed.

The Brookhaven National Laboratory (BNL) program for the utilization of waste glass in construction materials is an outgrowth of previous work on concrete-polymer materials. ${ }^{1}$ One of the materials developed in that program is polymer concrete (PC) which consists of a mixture of fine and coarse aggregate and a polymeric binder. The material can be mixed and placed using conventional equipment, cures rapidly at ambient temperature, and has strength and durability properties that exceed those of portland cement concrete.

In 1973 experiments were performed at BNL which indicated that glass and paper could be used.as aggregate in PC formulations. 2 Potential applications as construction materials for sewer pipe, building block, chemical storage tanks, and insulating panels for use in energy storage systems were identified. 
The particular application of GPC sewer pipe appeared quite attractive because of its high strength and durability to acids which exist in municipal sewage. GPC is far superior to concrete in these properties and potentially less energy intensive and less costly than vitrified clay and asbestos cement which are presently specified for sewage systems. Furthermore, this application takes a waste material generated by a municipality and converts it to a product which can readily be used by that same municipality.

Based upon the above work, a preliminary cost analysis was performed ${ }^{3}$ and a technology transfer program was initiated. ${ }^{4}$ The latter resulted in the establishment of a cooperative program with an industrial company (Teledyne Nationa1) to utilize the glass fraction from a large urban waste plant in operation in Maryland.

In June 1976 the Office of Conservation of DOE (formally ERDA) initiated support of the program. The goals for the program are as follows:

1. To provide the technical basis for energy conservation by the development, testing, and practical demonstration of products made from industrial waste materials.

2. Rapid transfer and implementation of the technology in the private sector.

The program goals are being achieved by performance of the following tasks:

1. Determine the properties of GPC sewer pipe to a degree that they are statistically acceptable with respect to relevant ASTM methods and standards. 
2. Perform field testing of prototype and full-scale specimens.

3. Prepare energy budgets and cost analyses.

4. Involve the solid waste: utilization industry in a11 phases of the program in order to provide a technical basis for the rapid implementation of the technology.

To date six progress reports on the program have been issued. ${ }^{5-10}$ Accomplishments during the period January-March 1978 are summarized in the current report.

Summary of Previous Report ${ }^{10}$

Tests were started to determine the 1ong-term durability of glass polymer composite (GPC) pipe in hot water and $5 \% \mathrm{H}_{2} \mathrm{SO}_{4}$. Experiments to optimize the monomer concentration and particle size distribution of the glass fraction in the GPC were also being performed. These data will be utilized in calculations to determine the energy requirements and cost to produce GPC pipe as a replacement for vitrified clay, asbestos cement, and concrete pipe in sewage systems. Earlier calculations based upon as-produced properties indicated the use of GPC could result in energy savings of up to $16 \%$ and reductions in cost compared to vitrified clay from 11 to $44 \%$.

Field testing of full-size pipe was continuing at two locations. A test in a line containing $\mathrm{pH} 2.4$ waste was scheduled.

Task 1 GPC Property Measurements

During FY 1977 tests were performed to determine the minimum wall thickness of as-produced 8 -in.-i.d. GPC sewer pipe required to meet ASTM Standard $\mathrm{C}-76$. These results were summarized in Progress Report No. $5 .^{9}$ Work during FY 1978 has been directed towards the 
determination of the durability properties after long-term exposures to $5 \% \mathrm{H}_{2} \mathrm{SO}_{4}$ and flowing water at $65^{\circ} \mathrm{C}$. These test conditions were selected so that the results can be compared with Australian work ${ }^{11}$ on PC pipe which utilized $10,000 \mathrm{hr}$ exposure data to predict strength characteristics over a $100 \mathrm{yr}$ period in sewage systems.

As the initial part of the durability test effort, control samples of 8-in.-i.d. x 1.5-in.-wall GPC were fabricated during the previous report period. 10 The GPC formulation consisted of 88.25 wt\% glass from the Cockeysville, Maryland solid waste separation plant and $11.75 \mathrm{wt} \%$ of a polyester-styrene mixture. The monomer mixture consisted of $81 \mathrm{wt} \%$ styrene, $14.9 \mathrm{wt} \%$ of low viscosity polyester resin, and $4.1 \mathrm{wt} \%$ of a low shrinkage polyester. Prior to mixing with the glass fraction, a silane coupling agent, an internal release agent, and a polymerization initiator, each at a concentration of $1 \%$ by weight of monomer, were added to the monomer.

The GPC formulation was mixed in a conventional concrete mixer until all of the glass aggregate was wetted with monomer. It was then placed in the pipe forms and compacted using air-operated vibrators. A description of the forms is given in Ref. 6. The pipes were then cured in an oven at a temperature of $82^{\circ} \mathrm{C}$ for $4 \mathrm{hr}$.

Three-edge bearing strength measurements were performed on four 8-in.-1ong pieces of pipe. An average strength of $14,379 \pm 7641 \mathrm{~b} / \mathrm{ft}_{\mathrm{L}}{ }^{-}$ $\mathrm{ft}_{\text {id }}$ was measured (see Table 1). This value is in excellent agreement with a predicted value from previous work ${ }^{9}$ of $14,492 \pm 4101 \mathrm{~b} / \mathrm{ft}_{\mathrm{L}^{-\mathrm{ft}}}$ id and will be used as the initial strength in determining the effects of exposure to fluids on the strength properties of 1.5 -in.-wa11 pipe. 
Table 1

Three-Edge Bearing Strengths of GPC, Vitrified Clay and Asbestos Cement Pipe Prior to Long-Term Durability Tests

\begin{tabular}{|c|c|c|c|c|c|}
\hline $\begin{array}{l}\text { Batch } \\
\text { No. }\end{array}$ & $\begin{array}{c}\text { Wal1 } \\
\text { thickness, in. }\end{array}$ & $\begin{array}{l}\text { Three-edge } \\
\text { bearing. strength, } \\
\text { lb/ft } L^{-f t} i . d .\end{array}$ & Mean & $\begin{array}{l}\text { Standard } \\
\text { deviation }\end{array}$ & $\begin{array}{l}\text { Coefficient } \\
\text { of variation }\end{array}$ \\
\hline $302-1$ & 1.5 & 12828 & & & \\
\hline $302-2$ & & 13900 & & & \\
\hline $302-3$ & & 15922 & & & \\
\hline $302-4$ & & 14868 & & & \\
\hline Entire series & & & 14379 & 764 & $0: 05$ \\
\hline $\begin{array}{l}\mathrm{VC}-1 \\
\mathrm{VC}-2\end{array}$ & 1.0 & $\begin{array}{l}7942 \\
7706\end{array}$ & & & \\
\hline Entire series & & & 7824 & 167 & 0.02 \\
\hline $\begin{array}{l}\text { TR-1 } \\
\text { TR-2 } \\
\text { TR-3 } \\
\text { Entire series }\end{array}$ & 0.625 & $\begin{array}{l}6777 \\
7526 \\
6897\end{array}$ & & & \\
\hline Entire series & & & 7067 & 284 & 0.04 \\
\hline
\end{tabular}


During the current report period control strengths were measured for 8 -in.-i.d. sections of asbestos cement sewer pipe conforming to ASTM Specification C 428-76 and vitrified clay pipe meeting specification

C 700-75. These data, also summarized in Table 1, will be used to determine the effects of the environmental conditions on the strength properties of the materials.

Previously reported data ${ }^{9}$ for the three-edge bearing strength of GPC as a function of wall thickness is given in Figure 1. From this figure it is apparent that a 1-in.-wa11 GPC pipe will have strength characteristics similar to those of the asbestos cement and vitrified clay pipe. It is planned to fabricate GPC of this size during the next report period for use in the durability tests.

Durability tests in $65^{\circ} \mathrm{C}$ water and $5 \% \mathrm{H}_{2} \mathrm{SO}_{4}$ at $20^{\circ} \mathrm{C}$ were started during the report period. The former are being performed in a 5-ft-diam x 15-ft-long stainless steel autoclave previously used for the impregnation of concrete pipe. The water is heated using steam. The temperature gradient within the vessel is minimized by circulating the water at $\sim 25 \mathrm{gpm}$.

Fifteen pipe sections ( 6 GPC, 6 asbestos cement and 3 vitrified clay) are currently being exposed to the hot water environment. The test was started on March 29, 1978 and the first strength measurements will be made after exposure for $\sim 4$ months. At that time, 3 samples of each material type will be tested. Additional specimens are being prepared for inclusion in the test series.

Testing in $5 \% \mathrm{H}_{2} \mathrm{SO}_{4}$ solutions is also in progress. This work is being performed in a manner similar to that described above except that 


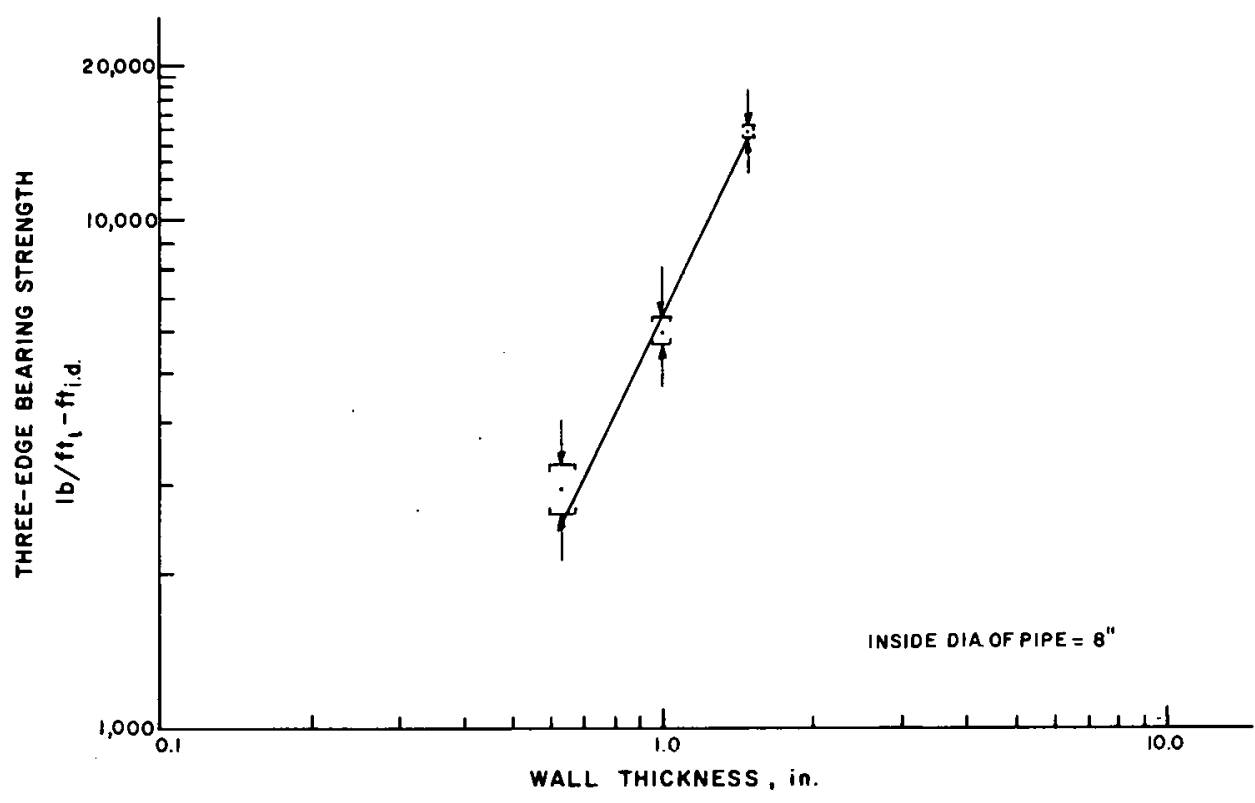

Figure 1. Three-edge bearing strength of Glass Polymer Pipe. 
the pipe sections are contained in closed glass battery jars. A total of 6 pieces of pipe ( 3 GPC, 2 asbestos cement and 1 vitrified clay) are currently in test. Additional sections will be placed in test during the next quarter after additional battery jars are received.

Work to determine the minimum polymer content required to produce a high quality GPC was continued. Since the polymer is the most expensive and energy intensive material in the GPC process, it is extremely important to minimize the quantity used.

During the report period 3-in.-diam $\times 6$-in.-long test cylinders with polymer concentrations ranging from $12.5 \mathrm{wt} \%$ to $8.5 \mathrm{wt} \%$ were produced. Previous economic and energy estimates ${ }^{8,9}$ were made using polymer concentrations of $12.2 \mathrm{wt} \%$ and $12.5 \mathrm{wt} \%$, respectively. The samples were tested to determine the strength and the force required to de-mold the specimen. The tests to date indicate that reductions in polymer content from $12.5 \mathrm{wt} \%$ to $10.0 \mathrm{wt} \%$ result in the compressive strength increasing from a value of $~ 8000$ psi to 10,000 psi. For concentrations between 10.0 wt\% and $8.5 \mathrm{wt} \%$, the compressive strength remained essentially constant. The force required to release the cylinders from the molds decreased with decreased polymer concentrations.

Similar relationships between polymer concentration and strength have been noted with other PC systems. ${ }^{12}$ Dependant upon the particle size distribution of the aggregate, a specific quantity of polymer is required to fill all of the voids. Further increases in polymer content results in the formation of heterogeneous sections of polymer which reduce the cohesive force between the polymer and aggregate. 
Further work to define the optimum polymer content is planned. Sections of pipe will then be made using the optimized mix for use in strength and hydrostatic tests and in determination of the mold release characteristics.

Task 2. Field Test and Inspection

Monitoring of the performance of GPC currently in test at Huntington, New York and Newark, New Jersey is continuing. At Huntington, a total of $35 \mathrm{ft}$ of 8-in.-diam sewer pipe has been in test since October 1972. Two sections of pipe contain methyl methacrylate and eight others. contain polyester-styrene. To date no problems with the pipe have been reported. A visual inspection of the pipe was made in 1974. A second inspection, originally scheduled for the previous report period, has been rescheduled to later in FY 1978 .

Twelve feet of 12-in.-diam pipe has been in test in Newark since November 1975. The pipe is in an industrial part of the city and is exposed to acid-type waste from several chemical plants. Prior to installation the pipe was shown to conform to the ASTM strength and hydrostatic test specifications. The leakage rate at the joints was also measured as well below that specified by the city.

A TV inspection of the pipe was made during september 1976. No deterioration was apparent. A second inspection, originally scheduled for the previous report period, has been rescheduled to later in FY 1978 . Arrangements have been made to initiate a second test at Newark. In this test, two 5-ft lengths of 12-in.-diam pipe will be installed at a location where the $\mathrm{pH}$ in steady operation is 2.4 . The fabrication 
of the pipe was completed during the report period. Adaptors to connect the GPC to the existing vitrified clay pipe in the sewage line are being fabricated. Installation of the specimens has been delayed by poor weather. Hopefully, this will take place during the next report period.

\section{Task 3. Materials, Costs and Energy Estimates}

Estimates of the energy requirements and costs to produce GPC pipe based upon as-produced properties, were given in the previous progress reports. 8 These calculations indicated energy savings of up to $16 \%$ and reductions in cost compared to vitrified clay from 11 to $44 \%$.

Previous cost estimates ${ }^{9}$ were based upon an assumed polymer concentration of 12.2 wt\%. Based upon recent work discussed in Task 1 , it appears that it may be possible to reduce the polymer concentration from this value to about $9 \mathrm{wt} \%$. The effect of this change on the cost of GPC is considerable since the cost of all raw materials except glass will decrease by a factor of $\sim 0.74(9.0 / 12.2)$. This will reduce the annual cost of raw materials from $\sim \$ 724,000$ to $\$ 534,000$. Assuming a value for waste glass of $\$ 10 /$ ton, the production cost of GPC will be reduced to $\sim 8.5 \mathrm{c} / 1 \mathrm{~b}$. This is $\sim 12.4 \%$ less than the previous estimate of $9.7 \mathrm{c} / 1 \mathrm{~b}$. Earlier energy estimates ${ }^{8}$ were based upon a conservative polymer concentration of $12.51 \mathrm{wt} \%$. Since only the energy requirements for the resin were considered in those studies, a reduction in polymer concentration to $9 \mathrm{wt} \%$ would reduce the energy. requirements by $\sim 28 \%$. A comparison of the revised estimates for the energy required to produce GPC with that for the production of vitrified clay pipe is given in Table 2. Energy savings ranging between 16 and $40 \%$ are indicated. 
Table 2

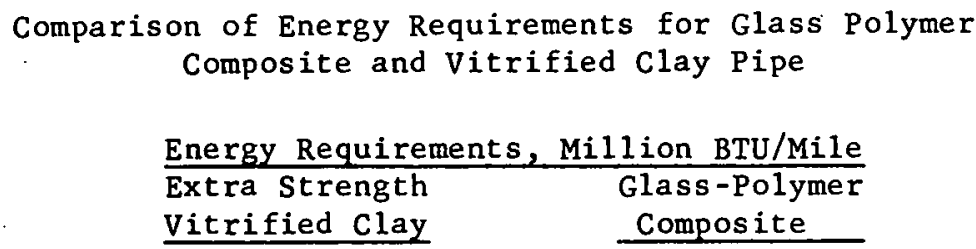

\section{Nomina 1 Size}

4

6

8

10

12

15

18

21

24

27

30

33

36

39

42

Extra strength
Vitrified clay

235.4

371.4

626.4

885.7

1260.3

1992.2

3003.0

4218.9

5340.0

6589.4

7971.0

9483.2

11123.1

12896.0

14799.4
Composite

169.1

311.1

493.0

714.9

976.7

1526.0

1807.8

2762.2

3644.9

4357.4

5128.8

6311.9

7617.3

9044.8

10142.3
Energy Saving, \%

28.2

16.2

21.3

19.3

22.5

23.4

39.8

34.5

31.7

33.9

35.6

33.4

31.5

29.9

31.5

a, ASTM Specification C700-75 
1. Steinberg, M., Dikeou, J. T., et al., Concrete-Polymer Materials, First Topical Report, BNL 50134 (T-509) and USBR Gen. Rept. 41, December 1968.

2. Beller, M. and Steinberg, M., Glass Polymer Composites, BNL 17555, January 1973.

3. Lindstrom, R. S. and Milgrom, J., Glass Polymer Composite Sewer Pipe, An Initial Evaluation of Its Commercial Potential, Arthur D. Little, Inc., C-74228, 1972 .

4. Steinberg, M., et al., Promoting the Utilization of Solid Waste - Glass Polymer Composite Technology in the Public and Private Sector, BNL 19394, October 1974.

5. Development of a Glass Polymer Composite Sewer Pipe from Waste Glass, Progress Report No. 1, July-September 1976, BNL 50577.

6. Development of a Glass Polymer Composite Sewer Pipe from Waste Glass, Progress Report No. 2, October-December 1976, BNL 50626.

7. Development of a Glass Polymer Composite Sewer Pipe from Waste Glass, Progress Report No. 3, January-March 1977, BNL 50662.

8. Development of a Glass Polymer Composite Sewer Pipe from Waste Glass, Progress Report No. 4, April-June 1977, BNL 50690.

9. Development of a Glass Polymer Composite Sewer Pipe from Waste Glass, Progress Report No. 5, July-September 1977, BNL 50737.

10. Development of a Glass Polymer Composite Sewer Pipe from Waste Glass, Progress Report No. 6, October-December 1977, BNL 50790.

11. Baker, C. A., Polymer Concrete: A Chemically Inert Structural Material, Humes Limited, Melbourne, Australia, 1973.

12. Cementing of Geotherma1 We11s, Progress Report No. 7, October-December 1977 , BNL 50808 . 


\title{
Distribution
}

\author{
DOE \\ Jerome F. Collins \\ David Schweller
}

BNL

K. C. Hoffman

J . Fontana

M. Ste inberg

L. E. Kukacka

D. H. Gurinsky

Teledyne

R. Rayfiel

R. S. Turley

Argonne National Laboratory

E. P. Lynch 
